\title{
Evaluation of Readmitted Patients After Intensive Care Unit Discharge (Retrospective Study)
}

\section{Yoğun Bakım Ünitesinden Taburcu Sonrası Tekrar Yatışı Yapılan Hastaların Değerlendirilmesi (Retrospektif Çalışma)}

\author{
(D) Pınar Öngel Çayören1, (D) Kerem Erkalp2, (D) Mehmet Salih Sevdi2, (D) Serdar Demirgan², \\ (D) Hüseyin Çayören³, (D Ayşin Selcan²
}

${ }^{1}$ Iğdır State Hospital, Clinic of Anesthesia and Reanimation, Iğdır, Turkey

2University of Health Sciences, İstanbul Bağcılar Training and Research Hospital, Clinic of Anesthesia and Reanimation, İstanbul, Turkey

${ }^{3}$ Iğdır State Hospital, Clinic of General Surgery, Iğdır, Turkey

\section{Abstract}

Objective: Nearly \%10 of the discharged patients are readmitted to intensive care unit (ICU) at the same hospital stay. Reduction of readmission rates could be used as a hospital performance indicator. Our aim is to analyse the reasons and results of readmissions of patients who were discharged to a general ward from ICU in a two-year period.

Method: Readmissions of the patients who had been treated in our ICU between the dates of 01.01.2015-31.12.2016 were analysed retrospectively. Demographic characteristics of patients, readmission rates, initial admission indications and comorbidities, distribution of readmission indications, timing of readmission after discharge, distribution of patients in terms of mechanical ventilation need, discharge time of readmitted patients at initial admission to ICU after weaning, readmission mortality rates, Glasgow Coma Scale (GCS), APACHE-II and SOFA scores of patients at initial admission and readmission were analysed and compared.

Results: 59 patients (3.55\%) are readmitted to ICU after discharge at the same hospital stay. When examining the departments where the readmitted patients came from, it is seen that 19 patients $(32.2 \%)$ were readmitted to ICU from department of general surgery. 22 of readmissions (37.29\%) occurred within first 48 hours after discharge. The most common reasons of readmissions are for postoperative monitoring after revisional surgery $(44.07 \%)$ and acute respiratory failure (40.68\%)

Conclusion: The patients who are discharged from ICU are at a high risk of being readmitted to ICU (35). Readmission to ICU is associated with higher mortality risk than the initial admission. The first step of reducing

\section{Öz}

Amaç: Taburcu edilen hastaların yaklaşık \%10' u yatış süresi içerisinde yeniden yoğun bakım ünitesine (YBÜ) gitmektedir. YBÜ'ye yeniden yatış oranlarındaki azalma, hastane performansında bir kalite göstergesidir. Bu çalışmadaki amacımız, YBÜ'den hastane içine, iki yıllık süre içerisinde taburcu edilen hastaların yeniden yatışlarının nedenlerini ve sonuçlarını analiz etmektir.

Yöntem: 01.01.2015-31.12.2016 tarihleri arasında hastanemiz YBÜ'de tedavi edilen hastaların tekrar yatışları geriye dönük olarak incelendi. Hastaların demografik özellikleri, tekrar yatış oranları, hastaların ilk yatış endikasyonları ve yandaş hastalıkları, tekrar yatışların endikasyonlarına göre dağılımı, tekrar yatışın taburculuk sonrası ne zaman gerçekleştiği, mekanik ventilasyon ihtiyacına göre hastaların dağılımı, tekrar yatışı olan hastaların birinci kabullerinde weaning sonrası taburcu olma zamanı, tekrar yatışlardaki mortalite oranları, hastaların YBÜ'ye ilk ve tekrar yatışındaki Glasgow Koma Skalası (GCS), APACHE-II ve SOFA skorları incelenerek kıyaslandı.

Bulgular: YBÜ'den taburcu edilen ve hastaneden taburcu olmadan tekrar yatışı yapılan hasta sayısı 59 olarak bulundu $(\% 3,55)$. Hastaların tekrar geldikleri bölümler incelendiğinde en fazla $19(\% 32,2)$ hasta Genel Cerrahi Kliniği'ndendi. Tekrar kabul edilen hastaların 22'si $(\% 37,29)$ taburcu edildikten sonraki ilk 48 saat içinde gerçekleşti. Tekrar kabul edilen hastaların en sık nedenleri; revizyon cerrahisi sonrasında postoperatif monitorizasyon $(\% 44,07)$ ve akut solunum yetersizliği $(\% 40,68)$ olarak belirlendi.

Sonuç: YBÜ'den taburcu edilen hastalar, tekrar YBÜ'ye kabul için yüksek risk altındadırlar. Yoğun bakım ünitesine geri kabul, ilk kabulden çok

Address for Correspondence: Kerem Erkalp, University of Health Sciences, İstanbul Bağcılar Training and Research Hospital,

Clinic of Anesthesia and Reanimation, ístanbul, Turkey

E-mail: keremerkalp@hotmail.com ORCID ID: orcid.org/0000-0002-4025-7092 Received: 24.12.2018 Accepted: 23.01.2019

Cite this article as: Öngel Çayören P, Erkalp K, Sevdi SM, Demirgan S, Çayören H, Selcan A. Evaluation of Readmitted Patients After Intensive Care Unit Discharge (Retrospective Study). Bagcilar Med Bull 2019;4(1):10-15.

๑Copyright 2019 by the Health Sciences University, Bagcilar Training and Research Hospital Bagcilar Medical Bulletin published by Galenos Publishing House. 


\section{Abstract}

the rates of readmission to ICU process is to anticipate the patients who would be readmitted to ICU priorly and improve service wards healthcare quality.

Keywords: Readmission, intensive care unit, critical patient

\section{Öz}

daha yüksek mortalite oranları ile ilişkilidir. YBÜ'ye geri kabul oranlarını azaltmadaki önemli adım, önceden hastaları tanımak, tanımlamak ve servis bakım düzeylerini yükseltmektir.

Anahtar kelimeler: Tekrar yatış, yoğun bakım ünitesi, kritik hasta

\section{Introduction}

Readmission to intensive care unit (ICU) is frequently seen in critically ill patients $(1,2)$. Nearly $\% 10$ of patients who has been discharged from ICU to a ward are being readmitted to ICU at the same hospital stay (3). Readmission is a risky condition; it is associated with increased mortality and longer length of hospital stay $(4,5)$. Also the financial effects of treatment are remarkable, costs gets higher (6). Decrease in readmission rates to ICU is seen as a quality indicator of a hospital performance (7). First step of lowering readmission rates to ICU is to anticipate which patients could be readmitted.

In this study, our aim is to analyze the reasons and results of readmission to ICU of our hospital at a two year period.

\section{Material and Methods}

Readmissions of the patients who had been treated in our ICU between the dates of 01.01.2015-31.12.2016 were retrospectively analyzed by the approval University of Health Sciences İstanbul Bağcılar Training and Research Hospital Ethics Committee dated 27.12.2016 and numbered 2016/526.

Data of patients who were discharged to a general ward from 20 bed ICU and readmitted back in the same hospital stay were obtained from patient files and electronic patient record system.

Demographic characteristics of patients, readmission rates, initial admission indications and comorbidities, distribution of readmission indications, timing of readmission after discharge (within 48 hours it is considered as early readmission), distribution of patients in terms of mechanical ventilation need, discharge time of readmitted patients at initial admission to ICU after weaning, readmission mortality rates, Glasgow Coma Scale (GCS), APACHE-II ve SOFA scores of patients at initial admission and readmission were analyzed and compared.

Comparative statistical analysis was performed with NCSS (Number Cruncher Statistical System) 2007 Statistical
Software (Utah, USA). At analysis, descriptive statistical methods (mean value, standard deviation and percentile rank) were used as well as independent samples t-test for the comparison of two-sample groups, paired samples t-test for the comparison of repeated measures and chisquare test for the comparison of qualitative data. We considered $\mathrm{p}<0.05$ as statistically significant.

\section{Results}

One thousand-nine hundred ninety seven patients received treatment in our ICU during two years period. One thousand-six hundred sixty four patients were discharged $(83.32 \%)$ and 353 patients died (17.68\%) fifty-nine patients (3.55\%) were readmitted to ICU after discharge at the same hospital stay (\%3.55). Demographic characteristics of patients are shown in Table 1. When examining the departments where the readmitted patients came from, it is seen that 19 patients (32.2\%) were readmitted to ICU from department of general surgery. Sixteen patients $(27.12 \%)$ were readmitted to ICU from department of neurosurgery and 11 patients were readmitted to ICU from department of orthopedics and traumatology (Table 2). Twenty-two

Table 1: Demographic data of the patient: readmitted after intensive care unit discharged

$\mathrm{n}=59$

$\begin{array}{ll}\text { Age (year) } & 61.22 \pm 18.80 \\ \text { Gender (M/F) } & 39 / 20 \\ \text { Height (cm) } & 162.75 \pm 9.26 \\ \text { Weight (kg) } & 73.22 \pm 7.86 \\ \text { Indication for ICU } & 43(72.88 \%) \text { Postoperative monitoring } \\ \text { admission } & 5(8.47 \%) \text { Polytrauma } \\ & 5(8.47 \%) \text { Cerebrovascular diseases } \\ & 4(6.78 \%) \text { Acute respiratory failure } \\ & 1(\%) \text { Arrhythmia } \\ & 1(\%) \text { Sepsis } \\ \text { readmission } & 26(44.07 \%) \text { Postoperative monitoring } \\ & 24(40.68 \%) \text { Acute respiratory failure } \\ & 6(10.16 \%) \text { Sepsis } \\ & 3(5.08 \%) \text { Shock }\end{array}$

M: Male, F: Female, ICU: Intensive care unit 
patients' readmission (37.29\%) occurred within first 48 hours and 37 patients' readmission $(62.71 \%)$ occurred after the first 48 hours. Twenty-one (35.59\%) of 59 readmitted patients died, 38 (64.41\%) of them were discharged.

Mean length of stay was $6.58 \pm 7.44$ days for the living patients and $17.29 \pm 15.12$ days for dead patients. Second length of ICU stay of dead patients was longer than living patients $(\mathrm{p}=0.002)$. When readmitted patients were evaluated, mean initial length of stay was $5.89 \pm 10.59$ days for living patients and $6.19 \pm 10.56$ days for dead patients $(\mathrm{p}=0.878)$.

Mean length of ICU stay was $6 \pm 10.49$ days at initial admission and $10.39 \pm 11.87$ days at readmission. Mean length of ICU stay was longer at readmission than the initial admission $(\mathrm{p}=0.001)$.

Glasgow coma scale (GCS), APACHE-II ve SOFA scores of patients at initial admission and readmission were analyzed. Mean GCS score was $13.32 \pm 2.58$ at initial admission and $11.88 \pm 3.29$ at readmission. Mean GCS score was lower at readmission than the initial admission $(\mathrm{p}=0.005)$. Mean APACHE-II score was $11.46 \pm 4.60$ at initial admission and $15.47 \pm 6.15$ at readmission. Mean APACHEII score was higher at readmission than the initial admission ( $\mathrm{p}=0.0001$ ). Mean SOFA score was $1.59 \pm 1.48$ at initial admission and $2.66 \pm 2.05$ at readmission. Mean SOFA score was higher at readmission than the initial admission ( $\mathrm{p}=0.001$ ) (Table 3 ).

\section{Discussion}

Readmission to ICU within 48 hours after discharge is used as an important quality indicator by Society of Critical Care Medicine (8).

In our study, 59 patients have been readmitted to ICU during the same hospitalization (3.55\%). There is a wide

\begin{tabular}{lll}
$\begin{array}{l}\text { Table 2: Distribution of patients with readmission by their } \\
\text { clinic }\end{array}$ & & \\
Readmission to ICU from which clinic & Patients $(\mathbf{n = 5 9 )}$ & $\%$ \\
\hline General surgery clinic & 19 & 32.20 \\
Neurosurgery clinic & 16 & 27.12 \\
Orthopaedics and traumatology clinic & 11 & 18.64 \\
Urology clinic & 7 & 11.86 \\
Internal medicine clinic & 3 & 5.08 \\
Obstetrics and gynaecology clinic & 1 & 1.69 \\
Plastic, reconstructive and & 1 & 1.69 \\
aesthetic surgery clinic & 1 & 1.69 \\
Ear, nose and throat clinic & &
\end{tabular}

ICU: Intensive care unit
Table 3: Comparison of invasive mechanical ventilation support, GCS, APACHE II Score, SOFA score and length of ICU stay between first admission and readmission

\begin{tabular}{llll} 
& $\begin{array}{l}\text { First } \\
\text { admission }\end{array}$ & Readmission & p \\
\hline $\begin{array}{l}\text { Invasive mechanical } \\
\text { ventilation support (\%) }\end{array}$ & $35.60 \%$ & $62.71 \%$ & $<0.05$ \\
GCS & $13.32 \pm 2.58$ & $11.88 \pm 3.29$ & $<0.05$ \\
APACHE II Score & $11.46 \pm 4.60$ & $15.47 \pm 6.15$ & $<0.05$ \\
SOFA Score & $1.59 \pm 1.48$ & $2.66 \pm 2.05$ & $<0.05$ \\
Length of ICU stay (day) & $6.00 \pm 10.49$ & $10.39 \pm 11.87$ & $<0.05$ \\
\hline $\begin{array}{l}\text { GCS: Glasgow coma scale/score, APACHE: Acute physiology and chronic health } \\
\text { evaluation, SOFA: Sequential organ failure assessment, ICU: Intensive care unit }\end{array}$
\end{tabular}

range of readmission rates (5-17.5\%) in various studies $(1,2)$. Readmission rate was $9.6 \%$ in a study by Jo et al. (9). Rate of readmission to ICU within 48 hours after discharge and within 120 hours after discharge were $2 \%$ and $3.7 \%$ respectively in a study by Brown et al. (10). Our readmission rate is slightly less than that reported in the literature.

According to Amin et al. (1), reasons of readmission to ICU are deterioration or relapse of the disease, newly emerged complications irrelevant to initial admission and purpose of follow up with the patients who needs repeating surgery. In a study by Rosenberg et al. (4), it is reported that intensification of symptoms due to improper or delayed treatment may lead to readmission. Prolonged hospital stay and being older than 70 are amongst the risk factors associated with readmission to ICU. Cardivascular and respiratory system problems are prominent causes of readmission (11). Gajic et al. (12) highlight the importance of prolonged ICU stay and lower GCS at the day of discharge. Risk factors for readmission to pediatric ICU are being younger, emergency indications and the critical condition at initial admission (13). Male sex, history of DM, application of continuous renal replacement therapy (CRRT) during ICU stay, white blood cell count on the day of extubation and heart rate just before ICU discharge are also associated with increased risk of ICU (9). When examining the departments where the readmitted patients came from, it is seen that largest number of patients (32.2\%) were readmitted to ICU from general surgery clinic because of respiratory failure which is a result of repetitive surgeries for the medical condition.

$37.29 \%$ of patients' readmissions occurred within the first 48 hours after discharge from ICU. In the literature, cases of readmissions within 48 hours after discharge from ICU are considered as early discharges. Nearly $22-30 \%$ of the patients are early discharged $(14,15)$. Our early discharge 
rate is higher than that reported in the literature and the most probably reason for this is the bed scarcity that can't meet the high demand. However, there is no mortality rate difference between the patients who are readmitted to ICU within 48 hours or after 48 hours. Brown et al. (10), reported that there is no association between length of ICU stay and readmission to ICU within 48 hours after discharge. Risk factors for readmission within 48 hours are severity of disease, functional condition, length of mechanical ventilation, chronic respiratory or renal disease, chronic immunosuppression and presence of a solid organ tumour (10).

Readmission to ICU is directly proportional to the severity of disease scores $(15,16)$. GCS scores of our patients at readmission are lower than the initial admission. Mean APACHE-II scores at readmission are higher than the initial scores. Chan et al. (7) reported that APACHE-II scores of the patients who were readmitted to ICU and eventually died are the highest and higher APACHE-II score is associated with increased mortality risk. In our study, also average SOFA scores of patients at readmission are higher than the initial admission scores. Higher SOFA score measured at any time during ICU stay is associated with older age, emergency surgery and readmission to ICU (17).

Length of stay is longer and mortality rates are higher at readmission in our study. In a study by Wong et al. (18) the patients who were readmitted to ICU had longer length of stay and their mortality rates significantly increased. It is showed that nearly $22-44 \%$ of the patients had been early disharged from ICU (19). Rate of readmission to ICU is considered as a quality indicator, because it can be easily measured. Especially, rate of readmission within the first 4872 hours after discharge is advised as a clinical performance criteria (20). Even though readmission to ICU is associated with early discharge from ICU and poor clinical outcomes, there are considerable amount of studies in which there is not a convincing connection between readmission and objective quality criterias of an ICU $(21,22)$. It is seen that 10 of 21 patients (47.62\%) who needed mechanical ventilation at readmission to ICU have been discharged within first 48 hours after weaning. It is possible to say that if the patients' length of stay at ICU after weaning is shorter than 48 hours, they will be more likely to readmitted to ICU. We believe that the reason of this is the scarcity of bed capacity which is not enough for high demand and the new patients who require ICU care. Early discharge from ICU is one of the most important risk factors for the increased mortality
(23). In a study from USA in which more than two hundred thousand discharges from ICU to general wards have been examined retrospectively from hundred and fifty five ICUs, it is understood that length of ICU stay of the patients' gets shorter at the times when the demand for ICU beds arises (24). The patients are more likely to be readmitted to ICU after discharge at these times and it shows us that variations of ICU bed availability is so important that it could effect clinicians' triage decisions. In this high-volume study, despite the pressure of increased demand on triage decisions, in-hospital mortality rate and the probability of home discharge were not negatively effected. Strain spurs providers to reduce their provision of what seems to be lowvalue care by critically re-examining needs for ICU-level care and transferring patients who could be equally wellmanaged outside the ICU setting $(25,26)$. Consequently, readmission rates are lower in hospitals which have more ICU beds (27).

Respiratory failure is the most common reason of readmission to ICU in our study. For this reason, after discharging to general wards from ICU we may advice respiratory physiotherapy practices including aspiration, percussion and postural drainage by healthcare providers and a respiratory therapist which might be very beneficial and even could lower the readmission rate.

Choosing the right time to discharge a patient from ICU still remains a challenge (28). Discharging from ICU is protective against iatrogenic and nasocomial complications during ICU stay and it makes ICU available for efficient use and decreases costs (29). When considering the rewards, the decision of discharge from ICU may have some level of risk (30). Unfortunately, after being discharged from ICU to health facilities, the patients are at the risk of reduced monitoring which could lead to delayed recognition of probable complications and clinical deterioration $(31,32,33)$.

\section{Conclusion}

In conclusion, the patients who are discharged from ICU are at a high risk of being readmitted to ICU (34). Readmission to ICU is associated with higher mortality risk than the initial admission (35). Considering the funding for ICU services which consumes substantial amount of health resources, a decrease in the readmission to ICU rates can be used as a hospital performance indicator (36-38). The first step of reducing the rates of readmission to ICU process is to anticipate the patients who would be readmitted to ICU priorly and improve general wards healthcare quality (39-41). 


\section{Ethics}

Ethics Committee Approval: The study was approved by the University of Health Sciences İstanbul Bağcllar Training and Research Hospital Ethics Committee dated 27.12.2016 and numbered 2016/526.

Informed Consent: Retrospective study.

Peer-review: Externally peer-reviewed.

\section{Authorship Contributions}

Surgical and Medical Practices: P.Ö.Ç., K.E., M.S.S., S.D., H.Ç., Concept: P.Ö.Ç., K.E., A.S., Design: P.Ö.Ç., K.E., A.S., Data Collection or Processing: P.Ö.Ç., M.S.S., S.D., H.Ç., Analysis or Interpretation: P.Ö.Ç., K.E., A.S., Literature Search: P.Ö.Ç., K.E., M.S.S. Writing: P.Ö.Ç., K.E., H.Ö.

Conflict of Interest: No conflict of interest was declared by the authors.

Financial Disclosure: The authors declared that this study received no financial support.

\section{References}

1. Amin N, Divatia JV, Agarwal V, Kulkarni AP. Readmissions in a surgical intensive care unit: patient characteristics and outcome. Indian J Crit Care Med 2003;7:14-17.

2. van Sluisveld N, Bakhshi-Raiez F, de Keizer N, Holman R, Wester G, Wollersheim H, van der Hoeven JG, Zegers M. Variation in rates of ICU readmissions and post-ICU in-hospital mortality and their association with ICU discharge practices. BMC Health Serv Res $2017 ; 17: 281$

3. Alex J, Shah R, Griffin SC, Cale AR, Cowen ME, Guvendik L. Intensive care unit readmission after elective coronary artery bypass grafting. Asian Cardiovasc Thorac Ann 2005;13:325-329.

4. Rosenberg AL, Watts C. Patients readmitted to ICUs: a systematic review of risk factors and outcomes. Chest 2000;118:492-502.

5. Kramer AA, Higgins TL, Zimmerman JE. Intensive care unit readmissions in U.S. hospitals: patient characteristics, risk factors, and outcomes. Crit Care Med 2012;40:3-10.

6. Campbell AJ, Cook JA, Adey G, Cuthbertson BH. Predicting death and readmission after intensive care discharge. Br J Anaesth 2008;100:656-662.

7. Chan K, Tan CK, Fang CS, Tsai CL, Hou CC, Cheng KC, Lee MC. Readmission to the intensive care unit: An indicator that reflects the potential risks of morbidity and mortality of surgical patients in the intensive care unit. Surgery Today 2009;39:295299.

8. Nates LJ, Nunnally M, Kleinpell R, Blosser S, Goldner J, Birriel B, Fowler CS, Byrum D, Miles WS, Bailey H, Sprung CL. ICU admission, discharge, and triage guidelines: A framework to enhance clinical operations, development of institutional policies, and further research. Crit Care Med 2016;44:1553-1602.

9. Jo YS, Lee YJ, Park JS, Yoon HI, Lee JH, Lee CT, Cho YJ. Readmission to medical intensive care units: risk factors and prediction. Yonsei Med J 2015;56:543-549.
10. Brown SES, Ratcliffe SJ, Halpern SD. Assessing the utility of ICU readmissions as a quality metric: an analysis of changes mediated by residency work-hour reforms. Chest 2015;147:626-636.

11. Klimasauskas A, Kekstas G. Simple prediction of mortality in case of readmission to the intensive care unit. Crit Care 2007;11(Suppl 2):P469.

12. Gajic O, Malinchoc M, Comfere TB, Harris MR, Achouiti A, Yilmaz M, Schultz MJ, Hubmayr RD, Afessa B, Farmer JC. The stability and workload index for transfer score predicts unplanned intensive care unit patient readmission: initial development and validation. Crit Care Med 2008;36:676-682.

13. Odetola FO, Clark SJ, Dechert RE, Shanley TP. Going back for more: an evaluation of clinical outcomes and characteristics of readmissions to a pediatric intensive care unit. Pediatr Crit Care Med 2007;8:343-347.

14. Rosenberg AL, Hofer TP, Hayward RA, Strachan C, Watts CM. Who bounces back? Physiologic and other predictors of intensive care unit readmission. Crit Care Med 2001;29:511-518.

15. Ozbay HY, Bombaci, E, Ercan GC, Colakoglu S. Retrospective analysis of the re-admitted cases in intensive care unit; reasons, outcomes and evaluation of the factors that affect mortality. J Turk Soc Intens Care 2012;10:91-96.

16. Li Y, Chen D, Meike L, Ge XH, Xia ZJ. A study on causes of readmission to surgical intensive care unit and risk factors analysis of their prognosis. Zhonghua Wei Zhong Bing Ji Jiu Yi Xue 2013;25:403-407.

17. Woldhek AL, Rijkenberg S, Bosman RJ, van der Voort PH. Readmission of ICU patients: A quality indicator? J Crit Care 2017;38:328-334.

18. Wong EG, Parker AM, Leung DG, Brigham EP, Arbaje AI. Association of severity of illness and intensive care unit readmission: A systematic review. Heart Lung 2016;45:3-9.

19. Kramer AA, Higgins TL, Zimmerman JE. The association between ICU readmission rate and patient outcomes. Crit Care Med 2013;41:24-33.

20. Herbst LA, Desai S, Benscoter D, Jerardi K, Meier KA, Statile AM, White CM. Going back to the ward-transitioning care back to the ward team. Transl Pediatr 2018;7:314-325.

21. Son YG, Lee H, Oh SY, Jung CW, Ryu HG. Risk factors for intensive care unit readmission after liver transplantation: A retrospective cohort study. Ann Transplant 2018;23:767-774.

22. Bice T. ICU Readmissions: Good for reflection on performance but not a reflection of quality. Crit Care Med 2016;44:17901791.

23. Maharaj R. ICU readmission is a more complex metric than we first imagined. Crit Care Med 2018;46:2064-2067.

24. Kareliusson F, De Geer L, Tibblin AO. Risk prediction of ICU readmission in a mixed surgical and medical population. J Intensive Care 2015;3:30.

25. Rodríguez-Carvajal M, Mora D, Doblas A, García M, Domínguez P, Tristancho A, Herrera M. Impact of the premature discharge on hospital mortality after a stay in an intensive care unit. Med Intensiva 2011;35:143-149.

26. Amin A, Deitelzweig S, Christian R, Friend K, Lin J, Belk K, Baumer D, Lowe TJ. Evaluation of incremental healthcare resource burden and readmission rates associated with hospitalized hyponatremic patients in the US. J Hosp Med 2012;7:634-639. 
27. Wagner J, Gabler NB, Ratcliffe SJ, Brown SE, Strom BL, Halpern SD Outcomes among patients discharged from busy intensive care units. Ann Intern Med 2013;159:447-455.

28. Gumus F, Polat A, Yektas A, Erentug V, Alagol A. Readmission to intensive care unit after coronary bypass operations in the short term. Turk J Anaesthesiol Reanim 2014;42:162-169.

29. Seferian EG, Afessa B, Gajic O, Keegan MT, Hubmayr RD. Comparison of community and referral intensive care unit patients in a tertiary medical center: evidence for referral bias in the critically ill. Crit Care Med 2008;36:2779-2786.

30. Badawi O, Breslow MJ. Readmissions and death after ICU discharge: development and validation of two predictive models. PLoS One 2012;7:e48758.

31. Vollam SA, Dutton SJ, Young D, Watkinson PJ. Out-of-hours discharge from intensive care, in-hospital mortality and intensivecare readmission rates: a systematic review protocol. Syst Rev 2015;4:93.

32. Wong GE, Parker AM, Leung DG, Brigham EP, Arbaje AI. Association of severity of illness and intensive care unit readmission: A systematic review. Heart Lung 2016;45:3-9.

33. Pakbin A, Rafi P, Hurley N, Schulz W, Harlan Krumholz M, Bobak Mortazavi J. Prediction of ICU readmissions using data at patient discharge. Eng Med Biol Soc 2018;2018:4932-4935.

34. Christiansen CF, Flaatten H. Out-of-hours discharge from intensive care: certain about uncertainty. Intensive Care Med 2018;44:15451547.
35. Lin WT, Chen WL, Chao CM, Lai CC. The outcomes and prognostic factors of the patients with unplanned intensive careunit readmissions. Medicine (Baltimore) 2018;97:e11124.

36. Vollam S, Dutton S, Lamb S, Petrinic T, Young JD, Watkinson P. Outof-hours discharge from intensive care, in-hospital mortality and intensive care readmission rates: a systematic review and metaanalysis. Intensive Care Med 2018;44:1115-1129.

37. Wang HJ, Gao Y, Qu SN, et al. Preventable readmission to intensive care unit in critically ill cancer patients. World J Emerg Med 2018;9:211-215.

38. Lee H, Lim CW, Hong HP, Ju JW1, Jeon YT, Hwang JW, Park HP. Efficacy of the APACHE II score at ICU discharge in predicting post-ICU mortality and ICU readmission in critically ill surgical patients. Anaesth Intensive Care 2015;43:175-186.

39. Ofoma UR, Dong Y, Gajic O, Pickering BW. A qualitative exploration of the discharge process and factors predisposing to readmissions to the intensive care unit. BMC Health Serv Res 2018;18:6.

40. Rosa RG, Roehrig C, Oliveira RP, Maccari JG, Antônio AC, Castro Pde S, Neto FL, Balzano Pde C, Teixeira C. Comparison of unplanned intensive care unit readmission scores: A prospective cohort study. PLoS One 2015;10:e143127.

41. Desautels T, Das R, Calvert J, Trivedi M, Summers C, Wales DJ, Ercole A. Prediction of early unplanned intensive care unit readmission in a UK tertiary carehospital: a cross-sectional machine learning approach. BMJ Open 2017;7:e017199. 